IRA-International Journal of Management \& Social Sciences

ISSN 2455-2267; Vol.07, Issue 03 (2017)

Pg. no. 438-444

Institute of Research Advances

http://research-advances.org/index.php/RAJMSS

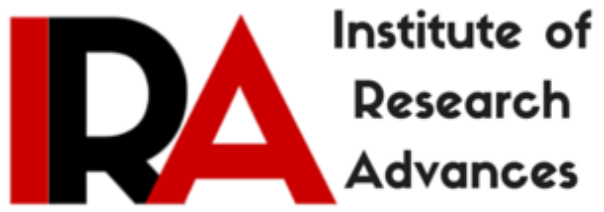

\title{
The Regulatory Framework for Investment in India
}

\section{Anamika Shekhawat}

PhD Scholar, Department of Economics, University of Rajasthan, Jaipur, India.

Type of Review: Peer Reviewed.

DOI: http://dx.doi.org/10.21013/jmss.v7.n3.p4

\section{How to cite this paper:}

Shekhawat, A. (2017). The Regulatory Framework for Investment in India. IRA-International Journal of Management \& Social Sciences (ISSN 2455-2267), 7(3), 438-444. doi:http://dx.doi.org/10.21013/jmss.v7.n3.p4

(C) Institute of Research Advances

\section{(c)) EY-NO}

This work is licensed under a Creative Commons Attribution-Non Commercial 4.0 International License subject to proper citation to the publication source of the work.

Disclaimer: The scholarly papers as reviewed and published by the Institute of Research Advances (IRA) are the views and opinions of their respective authors and are not the views or opinions of the IRA. The IRA disclaims of any harm or loss caused due to the published content to any party. 


ABSTRACT
The economic reforms initiated in the late eighties and early nineties in India have improved the
overall investment environment through market oriented policies. India's regulatory framework has
gradually become more enabling than restricting for investors. The once formidable administrative
burden has been substantially reduced since the announcement of the New Industrial Policy in 1991.
With the implementation of various reforms, India has certainly emerged as an attractive destination
for private investment, both foreign as well as domestic. However, investment remains insufficient to
meet India's massive needs. Certain factors as bureaucratic delays in business approvals, multiplicity
of procedures, policy and legal constraints, structural constraints, etc. still exist which prevent it
from realizing its true potential. An investor still has to undergo a lot of time consuming and complex
procedures that act as a disincentive for him.
The paper will make a comprehensive review of the regulations and procedures required for an
investment in India and draw out the lacuna of the present system. It will also suggest steps for
improving its performance in problematic areas such that the ease of doing business in India can be
enhanced.

\section{Objectives}

- To review the current investment scenario in India.

- To document the legislative and regulatory bottlenecks constraining investment in India.

- To make recommendations for facilitating enabling investment climate in India.

Keywords: Economic Reforms, Investment Environment, Regulatory Framework, Private Investment, Ease of Doing Business.

\section{Introduction}

India is the seventh largest country in the world by area and second largest by population. It has grown impressively in the past two decades and emerged as one of the fastest growing economies in the world. Gross national income per capita has nearly doubled since 2001, going from about US\$ 400 to about US\$ 800 . It has transformed from the world's $50^{\text {th }}$ ranked economy in nominal U.S. dollar terms in 1980 to the $10^{\text {th }}$ largest economy today. In terms of PPP, the Indian economy occupies fourth place in the world, after the U.S., Japan, and the Russian Federation.

\section{India an Attractive Destination for Investment}

Owing to its strong growth performance, a vast reservoir of cost-effective and skilled manpower coupled with a significant domestic demand for various goods and services, a large pool of educated and technically qualified workforce, robust regulatory structures and abundant and diversified natural resources, India has emerged one of the most attractive destinations for doing business in the recent years. Indian companies that earlier seemed averse to foreign companies are now becoming competitive and going global.

It offers immense opportunities for Business Process Outsourcing (BPO), Knowledge Process outsourcing (KPO) and Engineering Process Outsourcing (EPO) making India a front-runner in the emerging knowledge based economy.

\section{Global Perspective}

The UNCTAD World Investment Report 2013, in its analysis of the global trends in Foreign Direct Investment (FDI) inflows, has continued to report India as the third most attractive location for FDI for 2013-2015. 
Ernst \& Young's 2012 Attractiveness survey has mentioned India as the $1^{\text {st }}$ global destination for FDI, in terms of the number of FDI projects followed by Brazil and China. This is due to opening up of FDI in various sectors, including multi brand retail and telecom.

\section{Policy Reforms after Liberalization}

India has undergone a paradigm shift. Over the past three decades, it has transformed from its former rigidly controlled closed economy model into a more open and market-based economy. In the 1980s, government adopted partial liberalization in an attempt to modernize domestic industry and expand trade. It gathered substantial momentum in the early 1990s and further attenuated the strict investment regime. These were further renewed in the $2000 \mathrm{~s}$ with some more fundamental and positive changes in the economy.

Foreign trade Policy has been considerably relaxed with a progressive reduction in tariffs and abolition of quantitative restrictions on imports. A more open trade regime is replacing import substitution and protectionism. Foreign exchange restrictions related to FDI have been relaxed too.

With the announcement of FDI Policy 2013, most restrictions on foreign investment have been removed and procedures have been simplified. India now allows FDI in virtually all sectors except few. Moreover, investment ceilings, which are applicable in certain cases, are gradually being removed or phased out. In fact, FDI up to $100 \%$ is now allowed under the automatic route in most of the sectors.

\section{Investment Inflows in India are dismal}

Despite an open trade and foreign investment regime, considerable barriers to investment still remain which prevent it from realizing its true potential. India's performance in terms of attracting foreign investment has not been very encouraging. In fact, India attracts significantly lower levels of domestic and foreign investment than countries with similar incomes. The level of FDI that came into India as a percentage of total global investment was about $0.5 \%$ only while it was $1.6 \%$ of FDI stock received by the developing world in 2008 .

While India is the second most attractive country in terms of the foreign investors' confidence index measured by UNCTAD, it ranked at a dismal 106 out of 141 countries in the FDI Performance Index in 2007 and at 84 out of 141 countries in the FDI Potential Index. India's rank in the World Bank's Doing Business Report 2015 was 142 among 189 countries, which improved to 130 in the Doing Business Report 2016.

FDI in India constituted about $10.4 \%$ of GDP in fiscal year 2007-08 which is much lower than the average ratio of $27.8 \%$ in the world as a whole and $29.2 \%$ in the developing world.It has also been observed that the realization of approved FDI into actual disbursements has been quite slow. Almost 50 percent of FDI projects that are approved by the government do not materialize.

\section{Review of Literature}

CII-KPMG (2014) in their report "Ease of Doing Business in India" tries to explore four key parameters of Doing Business such as land acquisition, starting a business, taxation and contract enforcement. It makes an attempt to highlight those areas of business regulations where some states have succeeded in attaining efficiency while some others are still striving to make some progress in this field so that the inefficient states could emulate the efficient ones.

World Bank (2014) in its report "Doing Business 2015: Going beyond Efficiency" investigates the regulations that enhance business activity and those that constrain it. It focus on regulations affecting 11 areas of business- starting a business, dealing with construction permits, getting electricity, registering property, getting credit, protecting minority investors, paying taxes, trading across borders, enforcing contracts, resolving insolvency, and labour market regulations. 


\section{Regulatory Framework for Investment}

An investment project has to pass through many stages from its approval to implementation. Although approval for investment is given quite readily, actual establishment and running is a cumbersome process and generates substantial implementation lags. Once a foreign investor has entered India, he is treated at par with Indian private investors and has to undergo similar set of procedures. An entrepreneur has to take into account numerous regulations and acquire a series of subsequent approvals from the central, state as well as local authorities. A few regulations faced by entrepreneurs in India are outlined below:

\section{(A) Business Regulations Enforced by Central Government of India}

\section{(a) Entry Regulations}

There is multiplicity of procedures and agencies dealing with project approvals and clearances. First, a foreign investor has to seek entry permission at the central level either through the FIPB route or the RBI (automatic) route. The latter requires submitting only a notification to the regional office of the RBI within 30 days of receipt of FDI while under the FIPB route; proposals are considered by the Ministry of Finance, Department of Economic Affairs (DEA).

Once an investment is approved, a major obstacle faced by private investors is the tedious and time consuming procedure of business registration. Currently, an entrepreneur must visit upto 5 different agencies to register for fee and tax collections. Across India, administrative burdens are still high in comparison with other countries in spite of the recent efforts to improve business registrations.

Starting a business in India requires a host of formalities, clearances and permits. India performs poorly in the ease of starting a business in World Bank's Doing Business Report 2017 and ranks 155 out of 190 economies whereas it ranked 151th in 2016. Starting a business takes an average 12 procedures and 34 days, and costs $47 \%$ of income pc.

\section{(b) Licensing Requirements}

The next step is to obtain the business license. India's industrial licencing system is governed by the Industries (Development and Regulation) Act of 1951 at the central level. With progressive liberalization and deregulation of the economy, most of the industrial licensing requirements have been eliminated with only a few exceptions. Licensing on an average requires 224 days in India.

The industrial license is granted by the Secretariat for Industrial Assistance (SIA), Government of India on the recommendation of a Licensing Committee. Industrial undertakings exempted from industrial license are required to file only Industrial Entrepreneur Memoranda (IEM) with the SIA.

\section{(c) Inspection Requirements}

A plethora of inspection and reporting requirements also regulate the operational phase of projects. These include complex system of maintaining multiple records and register seven for identical objectives, inspections by a number of regulatory bodies, periodic renewal of approvals/licenses, etc. These regulatory constraints impose a heavy burden on the project and hamper the ease of doing business.

A study by ASCI has listed at least 27 different kinds of inspections for industrial undertakings by various agencies. Most of these inspections are applicable to other projects as well.

\section{(d) Environmental Regulations}

The next important regulation relates to environment. The Government of India has enacted various laws under the Environment (Protection) Act, 1986.It addresses every aspect of environment protection like air, water, soil, noise, forest conservation, wildlife protection, species and their habitat, etc. Also, separate set of laws and rules exist for emission of hazardous wastes. Further, sector 
specific policies have also been evolved. The Ministry of Environment and Forests (MoEF) is the nodal agency for environmental regulations. However, several states have also enacted their separate legislations.

Under the EPA, statutory clearances relating to pollution control and the environment are necessary by the entrepreneur for setting up units in 31 categories of industries. This list includes petrochemical complexes, petroleum refineries, thermal power plants, cement, fertilizers, bulk drugs, dyes, papers etc. However, projects requiring investment less than Rs. 1 billion are exempted except in a few specified cases.

Environmental clearances for investment projects perhaps take the longest time and causes maximum delays to projects. They involve huge costs due to corruption, administrative delays, technical faults, etc. Moreover, environmental issues are highly sensitive and quite often lead to civil society activism and public protests. Therefore, this aspect requires careful handling at both levels of the governmentcentre as well as state.

\section{(e) Exit Regulations}

Bankruptcy laws and liquidation procedures are extremely critical in India. It is nearly impossible for firms to exit. Defaulting borrowers take refuge under the Sick Industrial Companies Act in order to avoid payment to creditors. Insolvency procedures are protracted further by the lack of adequate specialized resources among courts and tribunals and by the requirement of prior permission of the government before lagging off workers by firms employing more than 100 workers.

The exit rates for large industrial firms in India are very low. If the firm goes burst and want to exit, it may take anywhere between 15 and 25 years to wind up its operations and exit. Recent estimates show that over $60 \%$ of liquidation cases before the High Courts have been in process for more than 10 years.

\section{(B) Business regulations enforced at the State Level}

Once an investor gets central approval, it needs to approach the state governments for taking subsequent approvals. The state governments along with local bodies play a very important role in the implementation of the project. Case studies commissioned by the PMO have also shown that over $70 \%$ of the implementation issues actually pertain to the state governments.

\section{(a) Land acquisition and registration regulations}

The existing regulations for land acquisition are very long drawn and cumbersome. The complete process starting from identification of land to acquisition can take nearly 18 months to 2 years. Poor compensation and absence of a comprehensive and transparent rehabilitation and resettlement policy for displaced people are among the major reasons for protests and stalling of industrial projects. A new land acquisition act has been introduced in 2013 replacing the archaic act of 1894 . However, it has also not been very successful due to its anti-industry provisions.

While land availability in industrial and other specially developed areas by the State level agencies has been considerably streamlined, getting land outside such areas is still a very complex process. Proposals for conversion of agricultural land to non-agricultural purposes have to pass through many levels. In case of land situated in urban areas, a public notice inviting objections is often necessary, which considerably delays the process. In many cases clearances under the Urban Land Ceiling (Regulations) Act is also needed.

The land registration system in India is also faulty and has led to growing problem of fraud and land disputes. Most property owners do not have clear titles in India. Any prospective buyer who wants to verify the title has to undertake a tedious process of consulting various sources such as past transactions, mortgage deeds, revenue records and encumbrance certificate. Since land is a state level 
responsibility, the administration system of land registration and record keeping varies tremendously from state to state.

According to the World Bank's Doing Business 2016, India's land registration process is cumbersome and problematic, with a minimum of 7 procedures; inefficient, with an estimated registration time of 47 days; and burdensome with costs of registration measured at $7.7 \%$ of the property value.

\section{(b) Labour Regulations}

India has a plethora of labour laws, around 250 at the central and state levels together. These are opaque and burdensome and usually perceived to be worker protective. Moreover, they are decades old and are suffer from severe inflexibilities.

There are two primary concerns of labour laws. Firstly, the strict regulation stipulated in Part VB of the Industrial Disputes Act (IDA) 1947 (as amended in 1976) mandates the prior approval of the state government for layoffs, retrenchment or closure of industrial establishments employing more than one hundred workers. This approval is rarely granted. Another rigid law of Contract labour (Abolition and Regulation) Act (1970) permits contract labour only in 'non-core areas'. It also requires 21 days' notice and the consent of employees to change the nature of their job.

These rigidities in the labour laws impose substantial constraints on the employers to dismiss unproductive workers, to downsize if and when there is a downturn in business, or introduce a new technology. It provides little incentive for industrial employers even to hire labour. It curtails labour mobility, reduce the supply of low cost labour and stall the growth of formal employment. Instead to avoid complications, hiring contractual labour without social security benefits or termination protection is encouraged.

India's labour regulations are unusually complex. There is clear room for improvement. The Doing Business2007 Report of the World Bank confirms that all facets of India's labour regulations are more stringent than the average for South Asian countries The "difficulty of firing" workers in India, for instance is rated as 90 out of 100 , more than double the regional average. Firms must pay 79 weeks of salary in notice, severance, and penalties to dismiss a worker, compared with regional average of 75 weeks and East Asian and OECD averages of 44 and 35 weeks, respectively.

\section{Conclusion}

The low level of FDI is a serious constraint to sustained rapid economic development. Though India has significantly improved the business environment, problems prevail. With the passage of time and growing concerns over environmental, security, safety, public health, and other issues, the regulatory framework has gradually become more complex. While many of the regulations and procedures seem necessary, poor administrative mechanisms have emerged as key problem.

Moreover, there prevails a requirement of obtaining multiple clearances from different agencies for the same activity viz., labour welfare and safety; or in many cases multiple clearances from the same agency. This makes the compliance very difficult and cost ineffective.

Government needs to identify, map and review business regulations that are more cumbersome than others and can be done away without too many legislative hurdles. A comprehensive legislation may be enacted to dispense with the requirements of multiple approvals at both central and state level. The stipulation of maintaining separate registers under each Act for related subjects should also be done away with. Instead, a single register or electronically maintained database may be sufficient.

Thus, the government of India needs to undertake some concrete measures for investment promotion in a comprehensive and focused manner. The State and the Central government equally share the onus of providing an investment friendly environment. They need to work in a unified manner to lower the entrepreneurship barriers by re-engineering existing policies and procedures and improve India's world ranking. 


\section{References}

1. Aggarwal, Aradhna (2005), "The Influence of Labour Markets on FDI: Some Empirical Explorations in Export Oriented and Domestic Market Seeking FDI Across Indian States", University of Delhi, Delhi.

2. CII-KPMG (2014), Report on Ease of Doing Business in India 2014.

3. CUTS Centre for Competition, Investment \& Economic Regulation (2003), Investment Policy in India- Performance and Perceptions.

4. FICCI (2006), Investing in India. KPMG

5. FICCI (2012), "India Infrastructure Summit 2012:Accelerating Implementation of Infrastructure Projects". New Delhi: Ernst \& Young Pvt. Ltd.

6. Government of India (2002), Report of the Steering Group on Foreign Direct Investment. New Delhi: Planning Commission, Government of India.

7. Government of India (2002), Report on Reforming Investment Approval and Implementation Procedures: Part IInvestment Approval Procedures - Government and Public Sector Projects. New Delhi: Cabinet Secretariat, Government of India.

8. Government of India (2002), Report on Reforming Investment Approval and Implementation Procedures: Part II Downstream Issues- Implementation and Operation. New Delhi: Cabinet Secretariat, Government of India.

9. Investment Commission(2006), "Investment Strategy for India". New Delhi: Ministry of Finance, Government of India.

10. NCAER(2010), "FDI in India and its Growth Linkages". Department of Industrial Policy and Promotion, Ministry of Commerce and Industry, Government of India.

11. Sahoo, Pravakar (2014), "Making India an Attractive Investment Destination: Analyzing FDI Policy and Challenges". The National Bureau of Asian Research.

12. Singh, Vijay Vir and Siddhartha Mitra (2008), "Regulatory Management and Reforms in India", Background Paper for OECD, CUTS International.

13. Stern, Nicholas (2001), "Building a Climate for Investment, Growth and Poverty Reduction in India".Mumbai: The Export-Import Bank of India.

14. UNCTAD (2013), World Investment Report 2013 Global Value Chains:Investment and Trade for Development. Geneva: UN Publications.

15. World Bank (2016), Doing Business in India 2016. New Delhi: Oxford University Press. 